\title{
$P-285$ 細胞痋の臨床的検討
}

産業医科大学

日田＼cjkstart官、山田陽司、藤本直浩、杉田篤生

1979年7月産業医科大学病院泌尿器科開設以来1995年6月までの16年問に治療した腎細胞癌は131例であり手 術症例は110例、保存症例は21例であった。性別は男性93例(71\%)、女性38例(29\%)で年龄は13葴から83葴まで

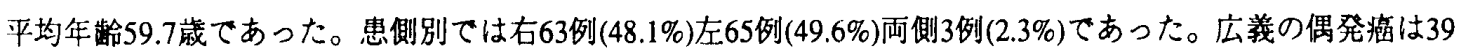
例 $(29.8 \%$ )であった。全症例の 5 年生存率は71.2\%であり、Stage-病期分類別 5 年生存率は、I 期 $100 \% 、$ II 期 81.9 \%、而期 $61.7 \%$ 、IV 期 $13.0 \%$ あった。手術症例で病理学的病期分類が確走した108例について1992年改定の腎 癌取り扱い規約に基づいて再検討し病理学的因子と予後について検討した。その他主訴、各種臨床検査值と予 後について検討したので報告する。

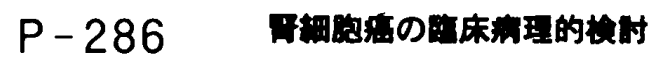

\section{绐满市立医案センター泌尿器科 武田英男 阿部 拓 佐薜僧夫}

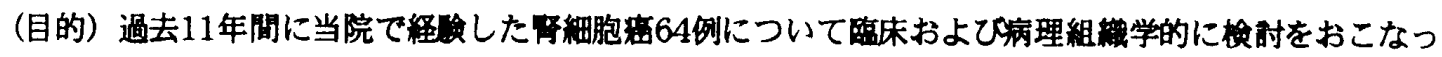
た。

（対象および方法）1984年4月より1995年3月までの11年間に当院において时揞除術を行った等細胞

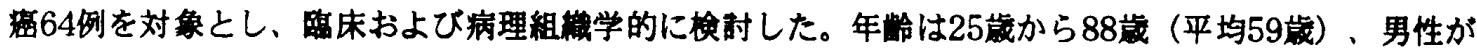
46名、女性が18名であった。生存率はKaplan-Meier法により算出し、Cox-Mantel法で㭘定した。

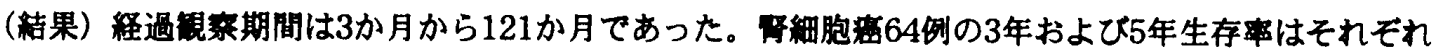

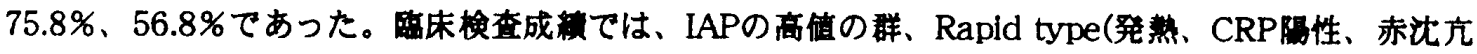

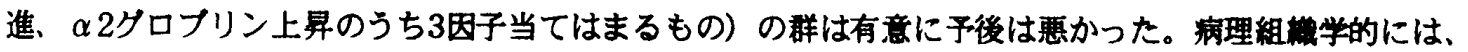
high grade , high stageの群は有意に予後が悪かった。組編学的細胞型で見ると、common typeは有

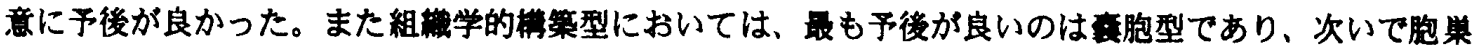

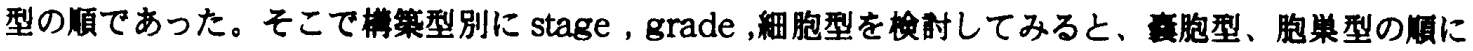

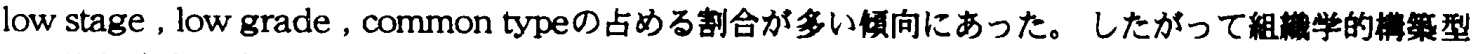
は、罗繧胞㾇の重要な予後因子となり得ると孝えられた。 